\title{
PENGARUH INVESTMENT OPPORTUNITY SET TERHADAP NILAI PERUSAHAAN DENGAN MEDIASI KEBIJAKAN DEVIDEN [Studi Empiris pada Emiten yang Tergabung dalam Index LQ45]
}

\author{
Billy Dharmawan ${ }^{1)}$, Fahrul Riza ${ }^{2) *}$ \\ ${ }^{1)}$ Program Studi Manajemen, Universitas Bunda Mulia \\ ${ }^{2)}$ Program Manajemen, Universitas Bunda Mulia
}

Diterima 12/12/18 / Disetujui 26/2/19

\begin{abstract}
This study l examine whether IOS and dividend policy have a positive direct effect on firm value, and whether dividend policy mediates the indirect influence of IOS on firm value on companies incorporated in LQ45. Pooled Least Squares analysis method was used. IOS was proxied with MVBVE, and dividend policy as a mediating variable was proxied with DPR. Firm value was proxied with Price Earning Ratio (PER). The samples taken were 27 companies from the population, namely companies incorporated in the LQ 45 index. The samples were chosen purposely, namely companies that were consistently in the LQ 45 index group for three consecutive years (2015-2017). Investment Opportunity Set has a significant positive effect on Company Value. Dividend policy has a significant positive effect on Corporate Value and dividend policy mediates partially the effect of no IOS on firm value
\end{abstract}

Keywords: Investment Opportunity Set, Devidend Payout Ratio, Firm Value

\section{ABSTRAK}

Penelitian ini akan menguji apakah $I O S$ dan kebijakan deviden memiliki pengaruh langsung yang posititif pada nilai peruasahaan, dan apakah kebijakan deviden memediasi pengaruh tidak langsung dari $I O S$ terhadap nilai perusahaan pada perusahaan-perusahaan yang tergabung pada LQ45. Metode penelitian yang digunakan adalah pooled least squares dengan variabel IOS yang diproksikan dengan MVBVE, kebijakan deviden dengan proksinya DPR sebagai variabel mediasi dan nilai perusahaan yang diproksikan menggunakan Price Earning Ratio (PER). Sampel yang diambil sebanyak 27 perusahaan dari populasi yaitu perusahaan yang tergabung dalam indeks LQ 45. Sampel dipilih secara puposif yaitu perusahaanperusahaan yang konsisten berada dalam kelompok indeks LQ 45 selama tiga tahun berturut-turut (2015 2017). Investment Opportunity Set berpengaruh positif signifikan terhadap Nilai Perusahaan. Kebijakan Dividen berpengaruh positif signifikan terhadap Nilai Perusahaan dan kebijakan deviden memediasi secara parsial pengaruh tidak dari IOS terhadap Devidend Payout Ratio (DPR), Nilai Perusahaan nilai perusahaan

Kata Kunci : Investment Opportunity Set, Devidend Payout Ratio, Nilai Perusahaan.

Korespondensi Penulis: friza@bundamulia.ac.id 


\section{PENDAHULUAN}

Nilai perusahaan merupakan salah satu indikator penting bagi para investor ketka akan membeli ataupun menjual saham pembelian dan penjulan di pasar modal. Harga pasar dianggap sebagai cerminan dari nilai aset perusahaan yang sesungguhnya (Sudiani \& Damayanti, 2016). Sehingga investor dapat mengukur nilai perusahaan dari harga pasar yang terjadi pada saat itu.

Teori perusahaan (theory of the firm) menyatakan bahwa tujuan didirikannya perusahaan untuk memaksimumkan kekayaan atau nilai perusahaan (value of the firm) (Dewi et al., 2018). Dengan nilai perusahaan yang tinggi maka akan meningkatkan kemakuran para pemangku kepentingan (stake holder) dan pemegang sahamnya (share holder). Bagi para investor di pasar saham, dengan memiliki saham perusahaan yang bernilai tinggi akan berpeluang mendapat deviden yang lebih besar dan kenaikan harga jual saham (capital gain) (Putra \& Lestari, 2016).

Nilai perusahaan dipengaruhi oleh Investment Opportunity Set (IOS), yaitu pilihan kesempatan investasi masa depan yang dapat mempengaruhi pertumbuhan aktiva perusahaan atau proyek yang memiliki net present value positif (Hidayah, 2015). IOS merupakan komponen penting dari nilai pasar (Kallapur \& Trombley, 2001) karena IOS mempengaruhi cara pandang manajer, pemilik, investor dan kreditor terhadap perusahaan. Besarnya IOS tergantung pada pengeluaran-pengeluaran yang ditetapkan manajemen dimasa yang akan datang, yang pada saat ini merupakan pilihan-pilihan investasiyang diharapkan akan menghasilkan return yang lebih besar (Gaver, 1993).

Beberapa penelitian secara empiris membuktikan bahwa IOS berpengaruh positif terhadap nilai perusahaan (Rachmawati \& Triatmoko, 2007). Hidayah (2015) menggunakan nilai CAPBVA dan MVBVE untuk memproksikan Invesment Opportunity Set menghasilkan temuan dimana kedua variabel tersebut memberikan pengaruh yang positif terhadap nilai perusahaan.

Nilai perusahaan juga bergantung dari keputusan keuangan yang diambil oleh perusahaan (Purnama 2016). Satu keputusan yang diambil akan berdampak pada keputusan lainnya. Keputusan-keputusan tersebut akan membentuk image dari perusahaan. Salah satu keutusan keuangan perusahaan yaitu kebijakan deviden yang memutuskan apakah laba yang diperoleh akan dibagikan atau ditahan untuk kebutuhan perusahaan di masa yang akan datang (Putra \& Lestari, 2016).

Menariknya, kebijakan deviden merupakan hal yang masih diperdebatkan oleh para pakar karena adanya dua teori yang bertentangan. Miller \& Modigliani (1961) dengan teori dividend irrelevance-nya menyatakan bahwa nilai perusahaan ditentukan oleh aset dan arus kas yang dihasilkan oleh aset tersebut. Sehingga dalam teori ini pendistribusian arus kas ke pemegang saham tidak berdampak pada kenaikan nilai perusahaan (Baker \& Weigand, 2015).

Sebaliknya teori devidend relevance yang mengacu pada signalling theory of devidend menganggap pemberian deviden kepada para pemegang saham menjadi sinyal positif bagi publik bahwa perusahaan memiliki prospek masa depan yang baik. Teori ini sependapat dengan teori bird in the hand bahwa pembagian dividen yang lebih tinggi, kestabilan dalam pembagian dividen setiap periode dapat meningkatkan nilai perusahaan. Hal ini karena dividen merupakan return yang pasti sedangkan capital gain yang ditawarkan oleh peluang investasi tidaklah pasti (Baker \& Weigand, 2015).

Putri \& Nuraina (2018) dan Setiyawati et al. (2017) tidak menemukan pengaruh yang signifikan pembagian deviden terhadap harga saham. Hasil penelitian keduanya teori dividend irrelevance. Sebaliknya, Yuniati et al. (2016), Ayem \& Nugroho (2016), Putra \& Lestari (2016), Purnama (2016), dan Senata (2016) temuan penelitiannya mendukung teori dividend relevance. Kebijakan Dividen yang diproksikan melalui Dividend Payout Ratio (DPR) berpengaruh positif pada nilai perusahaan yang menunjukkan investor dihadapkan pada dua pilihan apakah hasil pengembalian dividen diberikan dalam bentuk tunai atau dalam bentuk pertumbuhan modal (capital gain). 
Ada beberapa faktor karakteristik perusahaan dapat secara langsung dan tidak langsung mempengaruhi kebijakan dividen dan nilai perusahaan, salah satunya adalah peluang investasi (Siboni \& Pouralli, 2015). Suartawan \& Yasa (2016) mendapatkan bahwa kebijakan dividen dipengaruhi oleh IOS dan memediasi pengaruh Investment Opportunity Set pada Nilai Perusahaan secara parsial. Hasil penelitian ini mengindikasikan bahwa investasi yang dilakukan perusahaan manufaktur memberikan tingkat keuntungan yang baik sehingga perusahaan dapat membagikan dividen yang tinggi. Ketika perusahaan mampu berinvestasi dengan baik dan kemudian mampu membagikan dividen kepada para pemegang saham pada saat yang bersamaan, maka hal tersebut akan direspon positif oleh pasar sehingga dapat meningkatkan nilai perusahaan.

Penelitian ini akan menguji apakah IOS dan kebijakan deviden memiliki pengaruh langsung yang positif pada nilai peruasahaan, dan apakah kebijakan deviden memediasi pengaruh tidak langsung dari IOS terhadap nilai perusahaan pada perusahaan-perusahaan yang tergabung pada LQ45. Dipilihnya perusahaan yang tergabung pada LQ45 karena perusahaan dalam kelompok tersebut terpilih sebagai perusahaan terlikuid berdasarkan jumlah dan nilai transaksi di pasar modal yang pastinya pergerakan harga saham perusahaan-perusahaan tersebut sangat cepat yang berarti sangat peka dan responsif terhadap Investment Opportunity Set dan Kebijakan Dividen sehingga cocok untuk dijadikan sebagai subjek penelitian. Selain itu, model penelitian yang sama belum pernah diuji pada perusahaan di kelompok ini.

\section{METODE PENELITIAN}

Penelitian ini adalah metode kuantitatif dengan model analisis Pooled Least Square $(P L S)$. Model PLS yang dibangun terdiri atas tiga variabel yaitu IOS sebagai variabel eksogen dengan proksinya MVBVE, kebijakan deviden sebagai variabel endogen pertama yang juga berperan sebagai variabel mediasi dengan proksinya adalah $D P R$, dan nilai perusahaan yang diproksikan menggunakan Price Earning Ratio (PER) sebagai variabel endogen ke dua.
Populasi penelitian ini adalah perusahaan yang tergabung dalam indeks LQ 45 dengan kriteria pemilihan sampel menggunakan purposive dengan kriteria yaitu perusahaan-perusahaan yang konsisten berada dalam kelompok indeks LQ 45 selama tiga tahun berturut-turut terhitung sejak tahun 2015 sampai dengan 2017. Dari penyaringan atas populasi tersebut maka didapat sebanyak 27 perusahaan yang konsisiten berada dalam indeks LQ 45 selama tiga tahun berturut-turut sehingga total jumlah data yang terkumpul adalah sebanyak 81 item $(\mathrm{N})$

Tahapan analisis atas data penelitian ini terdiri ata analisis deskriptif yang berfungsi untuk mendeskriptifkan atau memberi gambaran terhadap objek yang diteliti melalui sampel. Kemudian analisis inferensial yang berfungsi untuk menguji pengaruh secara parsial dan simultan dari ketiga variabel yang digunakan.

Tahapan pengujian model yaitu uji Chow, Hausman dan LM untuk menentukan mana model yang terbaik antara common effect, fixed effect dan random effecct. Setelah diketahui model yang terbaik, langkah selanjutnya adalah pengujian hipotesis secara parsial dan mediasi.

Model ekonometrik dari penelitian adalah sebagai berikut:

$\mathrm{PER}_{\mathrm{it}}=\beta_{0}+\beta_{1} \mathrm{MVBVE}_{\mathrm{it}}+\beta_{2} \mathrm{DPR}_{\mathrm{it}}$

PER $=$ Price Earning Ratio perusahaan i di tahun $\mathrm{t}$

MVBVE = Market to book value of Equity perusahaan i di tahun $\mathrm{t}$

DPR $=$ Devidend Payout Ratio perusahaan i di tahun $\mathrm{t}$

$\beta_{0}=$ konstanta persamaan 1

$\alpha_{0}=$ konstanta persamaanm 2

$\beta_{1}=$ koefisien regresi MVBVE

$\beta_{2}=$ koefisien regresi DPR

$\alpha_{1}=$ koefisien regresi DPR

\section{HASIL DAN PEMBAHASAN Analisis Deskriptif}

Nilai Perusahaan diproksikan menggunakan Price to Earning Ratio (PER). Closing Price dan EPS menggunakan mata uang Rupiah (nilai satuan penuh). Nilai 
Perusahaan terbesar pada tahun 2015 dengan PER sebesar 48.30287206 dimiliki oleh PT Unilever Indonesia Tbk dengan kode emiten UNVR sedangkan Nilai Perusahaan terkecil pada tahun 2015 dengan PER sebesar 2.217520841 dimiliki oleh PT Bank Rakyat Indonesia Tbk dengan kode emiten BBRI. Nilai Perusahaan terbesar pada tahun 2016 dengan PER sebesar 61.34259259 dimiliki oleh PT Summarecon Agung Tbk dengan kode emiten SMRA sedangkan Nilai Perusahaan terkecil pada tahun 2016 dengan PER sebesar 2.179167717dimiliki oleh PT Bank Rakyat Indonesia Tbk dengan kode emiten BBRI.

Nilai Perusahaan terbesar pada tahun 2017 dengan PER sebesar 60.89324619dimiliki oleh PT Unilever Indonesia Tbk dengan kode emiten UNVR sedangkan Nilai Perusahaan terkecil pada tahun 2017 dengan PER sebesar 6.649976529dimiliki oleh PT Bumi Serpong Damai Tbk dengan kode emiten BSDE.

Investment Opportunity Set

Berikut data yang digunakan untuk mengukur Investment Opportunity Set yang diproksikan menggunakan Market to Book Value of Equity (MBVE). Closing Price dan Total of Equity dalam mata uang Rupiah (nilai satuan penuh). Nilai Investment Opportunity Set terbesar pada tahun 2015 dengan MBVE sebesar 58.48124026 dimiliki oleh PT Unilever Indonesia Tbk dengan kode emiten UNVR sedangkan Investment Opportunity Set terkecil pada tahun 2015 dengan MBVE sebesar 0.989462058 dimiliki oleh PT Bank Tabungan Rakyat Tbk dengan kode emiten BBTN.

Investment Opportunity Set terbesar pada tahun 2016 dengan MBVE sebesar 62.93107223 dimiliki oleh PT Unilever Indonesia Tbk dengan kode emiten UNVR sedangkan Investment Opportunity Set terkecil pada tahun 2016 dengan MBVE sebesar 0.7427152 dimiliki oleh PT Lippo Karawaci Tbk dengan kode emiten LPKR. Investment Opportunity Set terbesar pada tahun 2017 dengan MBVE sebesar 82.4444252 dimiliki oleh PT Unilever Indonesia Tbk dengan kode emiten UNVR sedangkan Investment Opportunity Set terkecil pada tahun 2017 dengan MBVE sebesar 0.37215084 dimiliki oleh PT Lippo Karawaci Tbk dengan kode emiten LPKR.

\section{Kebijakan Dividen}

Kebijakan Dividen diproksikan menggunakan Dividend Payout Ratio (DPR). DPS dan EPS dalam mata uang Rupiah (nilai satuan penuh). Kebijakan Dividen terbesar pada tahun 2015 dengan DPR sebesar 1.200559583 dimiliki oleh PT Astra Agro Lestari Tbk dengan kode emiten AALI sedangkan Kebijakan Dividen terkecil pada tahun 2015 dengan DPR sebesar 0.114344611 dimiliki oleh PT Waskita Karya (Persero) Tbk dengan kode emiten WSKT.

Kebijakan Dividen terbesar pada tahun 2016 dengan DPR sebesar 0.953460621 dimiliki oleh PT Unilever Indonesia Tbk dengan kode emiten UNVR sedangkan Kebijakan Dividen terkecil pada tahun 2016 dengan DPR sebesar 0.053579083 dimiliki oleh PT Bumi Serpong Damai Tbk dengan kode emiten BSDE. Kebijakan Dividen terbesar pada tahun 2017 dengan DPR sebesar 1.838802898 dimiliki oleh PT Indocement Tunggal Prakarsa Tbk dengan kode emiten INTP sedangkan Kebijakan Dividen terkecil pada tahun 2017 dengan DPR sebesar 0.019558754 dimiliki oleh PT Bumi Serpong Damai Tbk dengan kode emiten BSDE.

\section{Uji Asumsi Klasik}

Grafik diatas menunjukkan bahwa data tersebar mengikuti garis diagonal yang berarti nilai residual terdistribusi secara normal.

\section{Normal P-P Plot of Regression Standardized Residual}

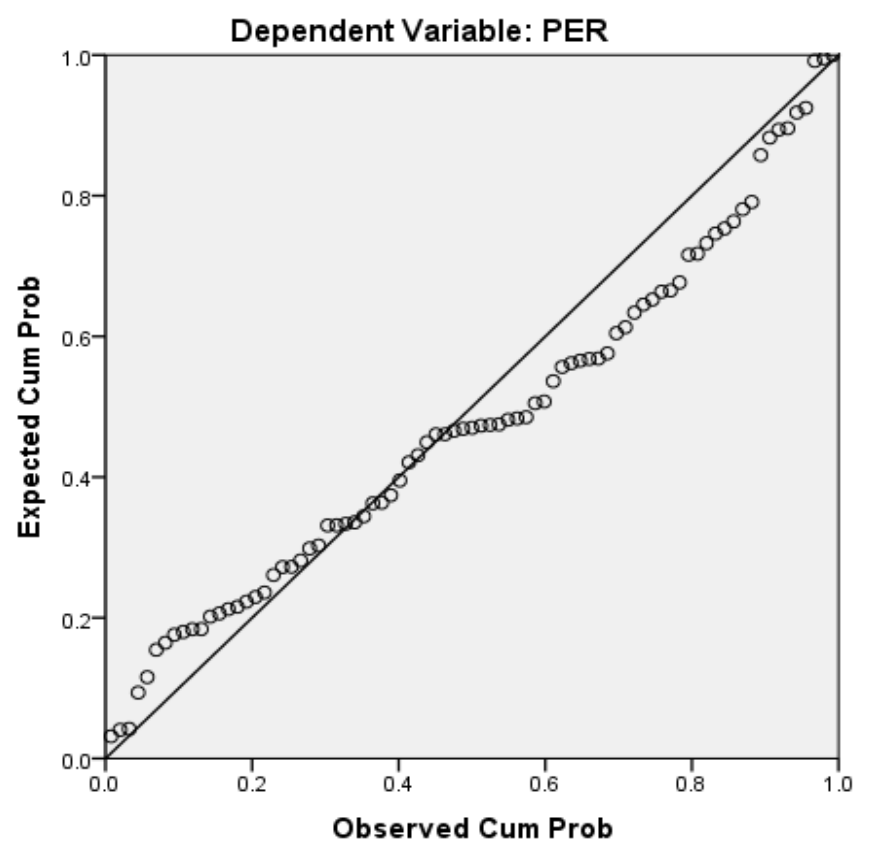




\section{Kurva Probability Plot}

Sumber: Data diolah peneliti menggunakan SPSS, 2018.

Nilai tolerance sebesar $0.895>0.10$ dan nilai VIF sebesar $1.118<10$ yang berarti tidak terjadi masalah multikolinearitas. Uji glejser menunjukkan koefisien regresi dari MBV signifikan pada r $0.340>0.05$ dan Sig. DPR sebesar $0.249>0.05$ yang berarti tidak terjadi masalah heteroskedastisitas.

\section{Pengujian Hipotesis}

\section{Uji t Persamaan Regresi 1}

Hasil uji persamaan regresi 1 diperoleh persamaan regresi sebagai berikut:

$\mathrm{PER}=13.982+0.401 \mathrm{MBVE}+9.256 \mathrm{DPR}+$ $\mathrm{e}_{1}$

\section{Uji t Persamaan Regresi 2}

Diperoleh persamaan regresi sebagai berikut:

$\mathrm{DPR}=0.410+0.008 \mathrm{MBVE}+\mathrm{e}_{2}$

Pengaruh Investment Opportunity Set terhadap Nilai Perusahaan

Investment Opportunity Set berpengaruh positif signifikan terhadap Nilai Perusahaan dan sesuai dengan hipotesis awal. Semakin besar peluang investasi yang dimiliki perusahaan, maka semakin besar juga nilai perusahaan. Hasil penelitian ini mendukung signaling theory yang menyatakan bahwa investor akan menerima sinyal positif dari perusahaan yang memiliki nilai IOS tinggi karena dianggap memiliki prospek pertumbuhan yang bagus di masa yang akan datang. Hal ini menunjukkan sinyal yang diberikan perusahaan-perusahaan LQ45 melalui peluang investasi (investment opportunity set) yang tinggi direspon positif oleh investor sehingga meningkatkan volume pembelian saham perusahaan-perusahaan LQ45. Dengan demikian, harga saham yang digunakan sebagai indikator nilai perusahaan juga akan meningkat (Wahyudi dan Pawestri, 2006 ; Suartawan \& Yasa, 2016). Hasil penelitian ini juga mendukung hasil penelitian Lestari (2014), Hidayah (2015), Sudiani \& Darmayani (2016), Astriani
(2014), Dewi et al (2018), dan Suartawan \& Yasa (2016).

Pengaruh Kebijakan Dividen terhadap Nilai Perusahaan

Kebijakan Dividen berpengaruh positif signifikan terhadap Nilai Perusahaan. Semakin besar pembagian dividen yang dilakukan perusahaan, maka semakin besar juga nilai perusahaan.Hasil penelitian ini mendukung signalling theory of dividend yang menyatakan tingkat pembayaran dividen untuk menyampaikan informasi private tentang prospek masa depan perusahaan kepada investor. Hasil penelitian ini juga mendukung bird in the hand theory yang menyatakan bahwa investor lebih menyukai perusahaan yang membagikan dividen karena adanya kepastian tentang return investasi serta dapat mengantisipasi risiko ketidakpastian tentang kebangkrutan perusahaan (Baker \& Weigand, 2015). Hal ini menunjukkan sinyal yang diberikan perusahaan-perusahaan LQ45 berupa pembagian dividen yang besar direspon positif oleh investor sehingga meningkatkan volume pembelian saham perusahaanperusahaan LQ45 dan meningkatkan harga saham yang digunakan sebagai indikator nilai perusahaan. Selain itu, pembagian dividen lebih kecil risikonya dibandingkan dengan capital gain sehingga pembayaran dividen yang tinggi akan meminimumkan biaya modal yang pada gilirannya akan meningkatkan nilai perusahaan (Sugiarto, 2011; Suartawan \& Yasa, 2016). Hasil penelitian ini juga mendukung hasil penelitian Yuniati et al. (2016), Ayem \& Nugroho (2016), Putra \& Lestari (2016), Purnama (2016), dan Senata (2016).

Pengaruh Investment Opportunity Set terhadap Kebijakan Dividen

Investment Opportunity Set berpengaruh positif signifikan terhadap Kebijakan Dividen. Semakin besar peluang investasi yang dimiliki perusahaan, maka semakin besar juga pembagian dividen yang dilakukan. Hasil penelitian ini mendukung life cycle theory yang menyatakan bahwa kemampuan perusahaan untuk menghasilkan 
uang melampaui kemampuannya untuk menemukan peluang investasi yang menguntungkan saat jatuh tempo. Dengan demikian, suatu perusahaan pada akhirnya harus mendistribusikan arus kas bebas kepada pemegang saham sebagai dividen. Perusahaan memutuskan kebijakan dividen optimalnya dengan hubungan antara pengembalian atas ekuitas dan biaya modalnya yang ditentukan oleh tahap siklus hidup perusahaan (Baker \& Weigand, 2015). Hal ini menunjukkan bahwa perusahaan-perusahaan LQ45 yang diteliti cukup mapan sehingga mampu mengelola keuangannya untuk meningkatkan peluang investasi yang dimiliki perusahaan dan juga meningkatkan pembagian dividen kepada investor secara bersamaan sehingga investor mendapatkan capital gain dan dividen secara seimbang. Hasil penelitian ini juga mendukung hasil penelitian dari Suartawan \& Yasa (2016), Putri (2013), danSari \& Budiartha (2016).

Untuk menguji pengaruh mediasi maka di gunakan Sobel test.

$$
\begin{aligned}
& \mathrm{a}=0.008 \\
& \mathrm{~b}=9.256 \\
& \mathrm{Se}_{\mathrm{a}}=0.003 \\
& \mathrm{Se}_{\mathrm{b}}=2.974
\end{aligned}
$$

$$
\text { thitung }=\frac{a b}{\sqrt{\left(b^{2} S e_{a}{ }^{2}\right)+\left(a^{2} S e_{b}{ }^{2}\right)}}
$$

$$
\text { thitung }=\frac{0.008 .9 .256}{\sqrt{\left(9.256^{2} 0.003^{2}\right)+\left(0.008^{2} 2.974^{2}\right)}}
$$

$$
\text { thitung }=2.025
$$

Dengan tingkat signifikansi sebesar 5\% atau 0.05 (two-tailed) dan degree of freedom (df) sebesar 78, maka t tabel sebesar 1.99085. Berdasarkan tabel diatas, $t$ hitung Sobel Test yang didapat sebesar $2.025>1.99085$ berarti Kebijakan Dividen memediasi pengaruh Investment Opportunity Set terhadap Nilai Perusahaan.

Kebijakan Dividen memediasi pengaruh Investment Opportunity Set terhadap Nilai Perusahaan karena semakin besar pembagian dividen yang dilakukan perusahaan dapat meningkatkan nilai perusahaan sedangkan pembagian dividen juga dapat ditingkatkan dengan cara meningkatkan peluang investasi berarti secara tidak langsung peluang investasi juga memengaruhi nilai perusahaan melalui kebijakan dividen. Hasil penelitian ini juga mendukung hasil penelitian Suartawan \& Yasa (2016).

\section{Tabel R Square}

Sumber: Data diolah oleh peneliti menggunakan SPSS, 2018.

Tabel diatas menunjukkan $\mathrm{R}$ Square sebesar 0.407 yang berarti dalam penelitian

Model Summary

\begin{tabular}{|l|c|r|r|r|}
\hline Model & $\mathrm{R}$ & R Square & $\begin{array}{c}\text { Adjusted R } \\
\text { Square }\end{array}$ & $\begin{array}{c}\text { Std. Error of } \\
\text { the Estimate }\end{array}$ \\
\hline 1 & $.638^{\mathrm{a}}$ & .407 & .392 & 8.8426535 \\
\hline
\end{tabular}

a. Predictors: (Constant), DPR, MBVE

kali ini Investment Opportunity Set dan Kebijakan Dividen mampu menggambarkan 40,7\% dari Nilai Perusahaan dan 59,3\% sisanya digambarkan oleh variabel-variabel lain yang tidak dimasukkan dalam penelitian.

\section{SIMPULAN}

Investment Opportunity Set memiliki pengaruh yang positif dan signifikan terhadap Nilai Perusahaan Invesment Opportunity Set yang diproksikan dengan MVBVE. Oleh karenanya perusahan harus mampu mengelola tambahan modal saham perusahaan untuk meningkatkan aktiva produktif sehingga berpotensi dalam meningkatkan nilai perusahaan. Perusahaan dengan nilai pasar yang tinggi dinilai baik oleh investor karena dapat memberikan return yang tinggi juga melalui harga saham yang tinggi.

Kebijakan deviden memiliki pengaruh yang positif dan signifikan terhadap nilai perusahaan. Kebijakan deviden pada penelitian ini diproksikan dengan menggunakan Dividend Payout Ratio. Oleh karenanya setiap perusahaan harus menentukan besarnya dividen yang dibagikan, karena penurunan maupun peningkatan jumlah dividen yang dibayarkan 
seringkali menjadi signal bagi pihak investor mengenai prospek pertumbuhan perusahaan di masa yang akan datang. Kebjakan deviden menjadi sinyal bagi investor untuk mengukur nilai perusahaan secara tidak langsung.

Investment Opportunity Set
berpengaruh positif signifikan terhadap Kebijakan Dividen. Semakin tinggi set peluang investasi yang dimiliki oleh perusahaan maka semakin besar porsi pembagian keuntungan yang diberikan oleh perusahaan kepada para investornya. Hasil pengujian mediasi menunjukkan bahawa Kebijakan Deviden memediasi secara parsial pengaruh tidak langsung dari Investment Opportunity Set terhadap nilai perusahaan.

\section{DAFTAR PUSTAKA}

Ardianto, M. J., Chabachib, M., Mawardi, W. (2017). Pengaruh Kepemilikan Institusional, Der, Roa, Dan Current Ratio Terhadap Nilai Perusahaan Dengan Kebijakan Dividen Sebagai Variabel Intervening (Studi Pada Perusahaan Manufaktur Di Bei Periode Tahun 2011-2015).

Astriani, E. F. (2014). Pengaruh Kepemilikan Manajerial, Leverage, Profitabilitas, Ukuran Perusahaan Dan Investment Opportunity SetTerhadap Nilai PerusahaanStudi Pada Perusahaan Manufaktur yang Terdaftar di Bursa Efek Indonesia Tahun 2009-2011.

Ayem, Sri \& Nugroho, Ragil. (2016). Pengaruh Profitabilitas, Struktur Modal, Kebijakan Deviden, Dan Keputusan Investasi Terhadap Nilai Perusahaan (Studi Kasus Perusahaan Manufaktur Yang Go Publik di Bursa Efek Indonesia) PERIODE 2010 2014. Jurnal Akuntansi 2016, 4(1).

Baker, H. K. \& Weigand, R. (2015). Corporate Payout Policy Revisited. Managerial Finance, Vol. 41 Iss 2 pp.http://dx.doi.org/10.1108/MF-032014-0077

Dewi, A. C. (2016). Pengaruh Investment Opportunity Set, Free Cash Flow, Struktur Modal, Profitabilitas Dan Likuiditas Terhadap Kebijakan Dividen(Studi Empiris pada Perusahaan Manufaktur yang terdaftar di Bursa Efek Indonesia Tahun 20122014).

Dewi, D. K., Tanjung, A. R., Indrawati, N. (2018). Analisis Pengaruh Free Cash Flow, Investment Opportunity Set, Ukuran Perusahaan Dan Kepemilikan Manajerial Terhadap Nilai Perusahaan Dengan Kebijakan Hutang Sebagai Variabel Moderating (Studi Pada Perusahaan Manufaktur Yang Listing) Di Bursa Efek Indonesia Periode 20122016. Jurnal Ekonomi 2018, 26(2).

Ghozali, Imam. (2011). Aplikasi Analisis Multivariate dengan Program SPSS. Semarang : Universitas Diponegoro.

Ghozali, Imam \& Ratmono, Dwi. (2013). Analisis Multivariat dan Ekonometrika : Teori, Konsep, dan Aplikasi dengan EVIEWS 8. Semarang : Universitas Diponegoro.

Hariyanto, M. S. \& Lestari, P. V. (2015). Pengaruh Struktur Kepemilikan, Ios, Dan Roe Terhadap Nilai Perusahaan Pada Perusahaan Food And Beverage. E-Jurnal Manajemen Unud, Vol. 4, No. 4, 2015:1599-1626/ISSN : 2302-8912

Hidayah, N. (2015). Pengaruh Investment Opportunity Set Dan Kepemilikan Manajerial Terhadap Nilai Perusahaan Pada Perusahaan Property Dan Real Estat Di Bursa Efek Indonesia. Jurnal Akuntansi, XIX(3), 420-432.

Juliana, Nasir, A., Anisma, Y. (2015). Pengaruh Kepemilikan Manajerial, Kebijakan Hutang, Profitabilitas, Ukuran Perusahaan Dan Investment Opportunity Set Terhadap Kebijakan DividenPada Perusahaan ManufakturYang Terdaftar Di BeiTahun 2011-2013.

Lestari, H. P. (2014). Pengaruh Investment Opportunity Set (Ios), Leverage , Dan Dividend Yield Terhadap Nilai Perusahaan (Pada Perusahaan Sektor Industri Makanan Dan Minuman Yang Listed Di Bursa Efek Indonesia). Jurnal Keuangan Dan Ekonomi, 1(1).

Maulyantini, A., Indrawati, N., Kurnia, P. (2018). Pengaruh Profitabilitas, Kepemilikan Manajerial, Pertumbuhan Perusahaan, Efektivitas Usaha, Dan Investment Opportunity Set Terhadap Kebijakandividen (Studi Empiris Pada 
Perusahaan Manufaktur YangTerdaftar Di Bursa Efek Indonesia Pada Periode 2013-2015).

Purnama, Hari. (2016). Pengaruh Profitabilitas, Kebijakan Hutang, Kebijakan Deviden, Dan Keputusan Investasi Terhadap Nilai Perusahaan (Studi Kasus Perusahaan Manufaktur Yang Go Publik di Bursa Efek Indonesia) PERIODE 2010 - 2014. Jurnal Akuntansi 2016, 4(1).

Putra, AA N. D. A. \& Lestari, P. V. (2016). Pengaruh Kebijakan Dividen, Likuiditas, Profitabilitas Dan Ukuran Perusahaan Terhadap Nilai Perusahaan. E-Jurnal Manajemen Unud, Vol. 5, No.7, 2016: 4044 - 407/ISSN : 23028912

Putri, D. A. (2013). Pengaruh Investment Opportunity Set, Kebijakan Utang dan Ukuran Perusahaan terhadap Kebijakan Dividen Pada Perusahaan Manufaktur Yang Terdaftar Di Bursa Efek Indonesia (BEI). Jurnal Manajemen, 2, $1-13$.

Putri, E. A. \& Nuraina, E. (2018). Pengaruh Kebijakan Dividen, Kebijakan Hutang Dan Profitabilitas Terhadap Nilai Perusahaan Manufaktur Yang Terdaftar Di Bursa Efek Indonesia.

Ramadhan, W. A. (2016). Pengaruh Free Cash Flow, Investment Opportunity Set, Dan Sales Growth Terhadap Dividend Policy Pada Perusahaan Manufaktur Yang Terdaftar Di Bursa Efek Indonesia.

Santoso, Singgih. (2016). Panduan Lengkap SPSS Versi 23. Jakarta : Elekmedia Computindo.

Sari, N. L. P. P. \& Budiartha, I. K. (2016). Pengaruh Investment Opportunity Set (Ios) Pada Kebijakan Dividen Tunai Dengan Umur Perusahaan Sebagai Variabel Pemoderasi. E-Jurnal Ekonomi dan Bisnis Universitas Udayana 5.5 (2016) : 1335-1358/ISSN : 2337-3067.

Sari, R. R., Muharam, H., \& Sofyan, S. (2016). Analisis Pengaruh Investment Opportunities, Leverage, Risiko Pasar Dan Firm Size Terhadap Dividend Policy(Pada Perusahaan Manufaktur yang Terdaftar di Bursa Efek Indonesia Periode Tahun 2011 - 2014).

Senata, Maggee. (2016). Pengaruh Kebijakan

Dividen Terhadap Nilai Perusahaan Yang Tercatat Pada Indeks Lq-45 Bursa Efek Indonesia. Jurnal Wira Ekonomi Mikroskil 2016, 6(1).

Setiyawati, L.,Wahyudi, S., Mawardi, W.

(2017). Pengaruh Kebijakan Dividen,

Kebijakan Utang, Komisaris

Independen Dan Kepemilikan

Institusional Terhadap Nilai

Perusahaan Dengan Growth

Opportunities Sebagai Variabel

Moderating(Studi Pada Perusahaan

Non Keuangan yang Terdaftar di BEI

Periode Tahun 2012-2015).

Siboni, Z. M., \& Pourali, M. R. (2015). The

Relationship between Investment

Opportunity, Dividend Policy and Firm

Value in Companies Listed in TSE:

Evidence from IRAN. European Online

Journal of Natural and Social Sciences

2015, 4(1), 263-273.

https://doi.org/10.1002/pmic.20110013 5

Suartawan, P. A., \& Yasa, G. W. (2016).

Pengaruh Investment Opportunity Set

Dan Free Cash Flow Pada Kebijakan

Dividen Dan Nilai Perusahaan. EJurnal Akuntansi Universitas Udayana, 14(3), 2014-2044/ISSN: 2302-8559.

Sudiani, N. K. A. \& Darmayanti, N. P. A. (2016). Pengaruh Profitabilitas, Likuiditas, Pertumbuhan, Dan Investment Opportunity Set Terhadap Nilai Perusahaan.E-Jurnal Manajemen Unud,5(7), 2016: 4545-4547/ISSN : 2302-8912.

Sumarni, I., Yusniar, M. W., Juniar, A. (2016). Pengaruh Investment Opportunity Set Terhadap Kebijakan Dividen.

Sunyoto, Danang. (2016). Metodologi Penelitian Akuntansi. Bandung : PT Refika Aditama.

Suryana, F. N. \& Rahayu, S. (2018). Pengaruh Leverage, Profitabilitas, Dan Ukuran Perusahaan Terhadap Nilai Perusahaan(Studi Empiris pada Perusahaan Industri Barang Konsumsi Sub Sektor Farmasi yang Terdaftar di Bursa Efek Indonesia Tahun 2012- 
2016). E-Proceeding of Management, 5 (2) $2018: 2262-2269 /$ ISSN : 23559357.

Susilo, H., Dhiana, P., Andini, R. (2018). Pengaruh Kepemilikan Institusional, Free Cash Flow, Dan Investment Opportunity Set Terhadap Nilai Perusahaan Dengan Kebijakan Hutang Sebagai Variabel Intervening (Studi Kasus Pada Perusahaan Sektor Keuangan Yang Terdaftar Di Bei Periode 2013-2016).

Syardiana, G., Rodoni, A., Putri, Z. E. (2015). Pengaruh Investment Opportunity Set, Struktur Modal, Pertumbuhan Perusahaan, Dan Return On Asset Terhadap Nilai Perusahaan. Jurnal Akuntabilitas Vol. VIII No. 1, April 2015 Halaman 39 - 46/P-ISSN: 1979$858 \mathrm{X}$.

Utama, N. P. S. P. \& Gayatri. (2018). Pengaruh Profitabilitas, Investment Opportunity Set dan Free Cash Flow Pada Kebijakan Dividen. E-Jurnal Akuntansi Universitas UdayanaVol.22.2. Februari (2018): 976-1003/ISSN: 2302-8556. https://doi.org/10.24843/EJA.2018.v22. i02.p06

Utomo, M. Nur. (2014). Strategi Peningkatan Nilai Perusahaan Melalui Investasi Berbasis Green. https://www.researchgate.net/publicati on/282732799
Wijaya, B. I. \& Sedana, I. B. P. (2015). Pengaruh Profitabilitas Terhadap Nilai Perusahaan(Kebijakan Dividen Dan Kesempatan Investasi SebagaiVariabel Mediasi). E-Jurnal Manajemen Unud, Vol.4, No.12, 2015: 4477-4500/ISSN : 2302-8912

Yudiana, I. G. Y. \& Yadnyana, I. K. (2016). Pengaruh Kepemilikan Manajerial, Leverage, Investment Opportunity Set Dan Profitabilitas Pada Kebijakan Dividen Perusahaan Manufaktur.EJurnal Akuntansi Universitas Udayana,15(1)2016: 112-141/ISSN: 2302-8556

Yuliariskha, Fania. (2016). Pengaruh Keputusan Pendanaan, Keputusan Investasi Serta Kebijakan Dividen Terhadap Nilai Perusahaan (Studi Pada Perusahaan Manufaktur Yang Terdaftar Di Bei Periode 2008-2010).

Yuniati, M., Raharjo, K., \& Oemar, A. (2016). Pengaruh Kebijakan Deviden, Kebijakan Hutang Profitabilitas Dan Struktur Kepemilikan Terhadap Nilai Perusahaan Pada Perusahaan Manufaktur Yang Terdaftar Di Bursa Efek Indonesia Periode 2009-2014. Journal of Accounting, 2(2).

http://finance.yahoo.com

http://id.investing.com

http://www.idx.co.id

http://www.sahamok.com 